\title{
IN SEARCH OF A SOCIOLOGICAL EXPLANATION FOR THE EMOTIONAL TURN
}

\author{
Ana Marta González \\ University of Navarra, Institute for Culture and Society, Navarra, Spain
}

\begin{abstract}
The overwhelming presence of the emotions both in science and contemporary social life begs for an explanation from the point of view of the same social theory. Even though the works of Hochschild, Scheff or Illouz contain indications that allow for a theoretical link between the contributions of the sociology of emotions and the theories of late modernity advanced by contemporary social theorists, this link has not yet been explicitly developed in the literature. The purpose of this article is to call attention on this link by highlighting the role of emotions as sites of social reflexivity.
\end{abstract}

Keywords: social theory, reflexivity, emotions.

Resumo A presença massiva das emoções tanto na ciência como na vida social contemporâneas exige uma explicação do ponto de vista da mesma teoria social. Embora as obras de Hochschild, Scheff ou Illouz contenham indicações que permitem um enlace teórico entre as contribuições da sociologia das emoções e as teorias da modernidade tardia avançadas por teóricos sociais contemporâneos, tal ligação não se tem desenvolvido ainda de forma explícita. O objeto deste artigo é chamar a atenção sobre esta conexão, destacando o papel das emoções como lugares de reflexividade social.

Palavras-chave: teoria social, reflexividade, emoções.

Résumé La présence massive des émotions tant dans la science que dans la vie sociale contemporaine exige une explication du point de vue de la même théorie sociale. Bien que les travaux de Hochschild, Scheff et Illouz contiennent des indications qui permettent d'établir un lien théorique entre les contributions de la sociologie des émotions et les théories de la modernité tardive avancées par des théoriciens sociaux contemporains, ce lien n'a pas encore été développé de façon explicite. Cet article attire l'attention sur cette connexion, en mettant en avant le rôle des émotions comme lieux de réflexivité sociale.

Mots-clés: théorie sociale, réflexivité, émotions.

Resumen La abrumadora presencia de las emociones tanto en la ciencia como en la vida social contemporánea reclama una explicación desde el punto de vista de la misma teoría social. Aunque las obras de Hochschild, Scheff o Illouz contienen indicaciones que permiten un enlace teórico entre las contribuciones de la sociología de las emociones y las teorías de la modernidad tardía avanzadas por teóricos sociales contemporáneos, dicho enlace no se ha desarrollado todavía de manera explícita. El objeto de este artículo es llamar la atención sobre esta conexión, destacando el papel de las emociones como lugares de reflexividad social.

Palabras-clave: teoría social, reflexividad, emociones.

During the last few decades there have been extraordinary developments in the research on the emotions, not only in the realm of psychology (Ekman, 1994; Lazarus, 1994), medicine (Wassman, 2005; Alberti, 2006; Kagan, 2007), and neurology (Damasio, 1994; Ledoux, 1999) - areas in which this interest is something to be expected - , but more generally in the realm of the humanities and social sciences, where the emotions are not simply a subject matter of research but rather the perspective for a new epistemological turn, which in the meantime has been termed as "emotional turn" or "affective turn" (Lemmings and Brooks, 2014). 
Thus, during the 80s an entire subfield emerged, which became known as the sociology of emotions. After the pioneering work of authors such as Arlie Hochschild (2003 [1983], 2007), Thomas Scheff $(1990,1991,1994,1997)$, or Theodore Kemper (1990), advances in this subfield have been periodically documented by Jan Stets and Jonathan Turner in the two volumes of their Handbook of the Sociology of Emotions (2006 and 2014).

Likewise, a new historical perspective emerged in the Anglo-American context, specifically interested in the relationship between emotion and social change, linked to the names of Carol and Peter Stearns, with their path breaking work on anger (1986). The subject matter of this "psychohistory" (Stearns and Stearns, 1988), namely, the connections between the psychological and the institutional dimensions of historical change, can easily remind us of Elias' early work on the civilizatory process, which remains a reference for any scholar interested in exploring the relationships between emotions and social change (van Krieken, 2014). Indeed, for Elias,

[t]he moderation of spontaneous emotions, the tempering of affects, the extension of mental space beyond the moment into the past and future, the habit of connecting events in terms of chains of cause and effect - all these are different aspects of the same transformation of conduct which necessarily takes place with the monopolization of physical violence, and the lengthening of the chains of social action and interdependence. It is a "civilizing"' change of behaviour. (Elias, 1998: 55)

More recently, the focus on emotions has found outlets also in the sociological studies of Eva Illouz $(1997,2007,2008,2012)$ and Jack Barbalet (2002), as well as in the work of literature scholars such as Suzanne Keen (2007) or Patrick Hogan (2011). Likewise, not long ago, Mabel Berezin (2005) reviewed the presence of emotions in different branches of economics... In a way or another, each branch of knowledge, always within the limitations proper to its particular methodology, is casting light on the often hidden presence of emotions in contemporary practices and culture.

It could be argued that the emotional revolution in the human and social sciences has been largely possible because of a previous revolution in the philosophy of emotions, which underlined the cognitive dimensions included in human emotions. Especially since Anthony Kenny (1994 [1963], 1992) and Robert Solomon's (1976) works on emotions, there have been a growing number of philosophical studies that challenged the modern, as well as scientific, approach to emotions incorporated in the experimental sciences since William James, sparking a discussion, which still continues under different forms. In this occasion, I don't want to delve into that discussion (see González, 2011, 2015). Instead, I would like to inquiry about the causes of the "emotional turn" in the sciences, since, as far as I know, this move remains in need of a sociological explanation. Indeed: what are the sociological reasons behind the emotional turn that we are witnessing in so many sciences? 


\section{The emotional turn in the context of the change in the emotional regime}

The first point I would like to make is that there is no chance in the fact that the "emotional turn" in the sciences coincides with what we could call a change in the "emotional regime" (González, 2012) of western societies. This change in the emotional regime entails significant transformations in the rules regulating the expression of emotions in the private and public realms, apparent in a number of social and cultural phenomena: one need only think of contemporary consumption practices, in the development of an emotional style in organizations, in the expansion of social media, in the proliferation of self-narratives... practices, which obviously result in the creation of different emotional "climates" (de Rivera, 2014: 229), and are significant of a more general cultural change, expressed in a specific emotional culture.

Indeed: as Joseph de Rivera writes, "[a]lthough emotions are transitory, societies create a background of customs that constitute an emotional culture" (de Rivera, 2014: 218). Now, as I argue below, one of the most plausible reasons of the emergence of contemporary emotional culture is related to the effects of the increasing rationalization and individualization of our societies. For, on the one hand, the immediacy of emotions is experienced as a way of counteracting the abstract character of modern life; and, on the other, even if emotions can drive people apart, they are also experienced as the glue which binds people together, counteracting individualization.

From this perspective, much of our contemporary emotional culture could be seen as a reflection of those very processes of rationalization and individualization that, according to classical theoretical thinking, have deeply marked western societies. This is not to deny, in a more Durkheim vein, the role that ritual and collective emotions still play in developing a sense of collective identity and creating what Rosenwein calls "emotional communities", that is, "groups in which people adhere to the same norms of emotional expression and value - or devalue - the same or related emotions" (Rosenwein, 2006: 2). Still, while acknowledging, with de Rivera, the role of collective emotions for fostering group unity, I tend to consider this aspect as marginal to dominant cultural trends, fostering individualization.

In this context, the coincidence of the emotional turn in the sciences with the change in the emotional regime of our societies might be taken as a sign that there is no sharp line to draw between scientific research on emotions and the advent of contemporary emotional culture. After all, modern science has played a decisive role in shaping contemporary minds and culture, insofar as it has been a privileged vehicle of rationalization and individualization. Accordingly, current scientific interest in the emotions represents, to some extent, a paradoxical and mixed result, which unveils a prominent aspect of social reflexivity.

Given the rationalizing and individualizing impact of science on contemporary culture, current scientific interest in the emotions can be regarded as an instance of social reflexivity, whereby we are trying to correct previous self-conceptions, 
which were, in turn, partly derived of the scientific view of the world. We should consider that, since the $19^{\text {th }}$ Century scientific discoveries have been shaping the ways in which contemporary men and women think of themselves and frame their experience; but, also that, around the same time, the scientific image of the world, which has provided us with an objectifying view of nature, was perceived as not adequately capturing another important dimension of our modern self-conception.

Indeed, for the Romantics, Gefühl, sentiment, encompassed both mental and organic properties in a single human experience, which could not simply be reduced to the objectifying results of science (Martín Moruno, 2011). From this perspective, the thirst or nostalgia for emotions that we discover in certain developments of contemporary life - including the scientific research on the emotions - could also be explained as a thirst or nostalgia for the self in a world progressively colonized by scientific reason. In such a world, emotions and feelings stand out as privileged ways of achieving a particular sense of being alive, of having a personal experience of things.

Norbert Elias' sociological approach to sports constitutes a particularly conspicuous example of the paradoxes involved in the process of "civilization", which to a great extent can be read also as a process of rationalization. At some point, he wonders what sort of society is this, in which so many people practice and enjoy the sight of bloodless competition among individuals, without thereby suffering serious damage (Elias, 2003: 43), and he develops the view that "part of the tensions and passions that were earlier directly released in the struggle of man and man must now be worked out within the human being" (Elias, 1998: 60). This, however, cannot be done without a sophisticated self-control, which involves an increasing ritualization of behaviour (Elias, 1998: 106), which tames emotional reactions. Yet, achieving a balance between social requirements and individual expression or between personal involvement and scientific detachment are not easy tasks (Elias, 2003: 222-223). Along these lines, contemporary interest in emotions could perhaps be regarded as an unintended effect of excessive rationalization: to the extent that rationalization entails some sort of homogenization of behaviour, at a certain point it would trigger compensatory processes of "emotionalization" as a way of getting in touch with one's true self.

"Express yourself": this romantic imperative does not merely represent a reaction against abstract reason, but, above all stresses what Simmel would call "qualitative individualism". Yet, while the proliferation of studies on the emotions reflects a positive cultural evaluation of emotional expressivity, it also anticipates a problematization of emotions, characteristic of our times, both at the individual and social levels. This problematization is mirrored in the growing interest in "emotional intelligence", "emotional management" (Hochschild, 2003 [1983]), or the role of emotions in organizations (Fineman, 2007 [2000]); Bolton, 2000b, 2005; Bolton and Boyd, 2003; Theodosius, 2008); it is also mirrored in that widespread emotional lethargy from which, apparently, one can only escape by resorting to extreme experiences (Le Breton, 2004). More generally, all these developments reflect the constitution of a particular emotional regime, which, not surprisingly, is significantly shaped by the sciences and the media (Illouz, 1997, 2008). 
Now, while a multitude of factors could be invoked to explain the transformation towards the contemporary emotional regime, beyond all these partial explanations, the overwhelming presence of the emotions both in science and contemporary social life begs for an explanation from the point of view of the same social theory. This explanation, however, has yet to be given.

\section{Towards a sociological explanation of the current interest in the emotions}

For sure, the prominence of emotions in so many areas of contemporary culture science included - cannot simply be explained as a quasi-mechanical reaction to the arguably more rationalistic character of early modern life. The social logic of such a reaction deserves further and more detailed explanation, as well as a good amount of methodological modesty, for it could be argued that the clear and distinct division between reason and emotion assumed in that description is itself a modern construct that neglects the emotional debts of reason and the cognitive background of many emotions (Turner and Stets, 2009: 21). More precisely, it could be argued that the very diagnosis of our culture's particular "emotional culture" is conditioned by the epistemological tools deployed by modern social theory.

Indeed, while classic sociological theory did not ignore the affective dimension of human behaviour (consider Tönnies' "community effusion", Weber's "affective action" and "charisma", Pareto's "residues", Durkheim's "collective effervescence" or the analysis of certain forms of emotional interaction in Simmel), it is true that the main focus has been on rationality, and except for Elias's work on emotional control (Paster, 2015), the emotional side of behaviour has barely been dealt with within sociological theory until very recently (Cuin, 2001; Flam, 2002). This is why it would make good sense to revise the Weberian typology of action, in which so-called "affective action" appears to occupy a rather small place (González, 2016), and explore to what extent it can be used to explain our current emotional culture. For this, of course, one must overcome the distinction between utilitarian rationality and Kantian rationality. Long used to approach social action, this distinction scarcely leaves space to account for the expressive and creative dimensions of human behaviour that are so emphasized in Romanticism and in the theory of action which emerges within the context of American pragmatism (Joas, 1993: 11).

In the meantime, however, I think that the distinction between the rational and the emotional is still useful for studying the notable change in western societies' emotional regimes. This is especially obvious if we consider that, in contrast to the more "emotionally contained" character of the early modern world, late-modern societies display a peculiar combination of emotional management - still a matter of rationalization - and emotional exuberance, or excess, that cannot properly be accounted for in instrumental terms. Consumption practices are a case in point (Campbell, 2005 [1987]). Likewise, while any talk of "emotional management" emphasizes the role of reason in the control of emotional responses, the emotional exuberance 
displayed, for instance, at sporting-events (Peterson, 2014) conveys the sense of immediacy that we attribute to real experience. This is a particularly conspicuous example of the kind of "collective effervescence" that, according to Durkheim, was at the basis of solidarity, a "higher-order social emotion" made up of more primitive ones (Collins, 2014: 300), and elicited in the context of rituals. Yet, as suggested above, it seems to me that this kind of collective emotional phenomena are now easily re-absorbed in the routine of ordinary life, and their importance lies more in their power to reinforce individual emotional experiences than in generating a sense of solidarity (Dell' Aquila, 2014).

In light of these phenomena, there is room to suggest not only that Weber's rationalization thesis coexists with Durkheim's account of collective enthusiasm, but also that it provides the master narrative of our times: late-modern societies are more pervaded by rationalization and individualization than by any kind of collective emotions, even in those cases in which rationalization reaches its limits and emotional reactions emerge. Indeed, in spite of Weber's own references to emotional action and the role of charisma in social life - which will always bear witness to the role of emotions in society -, late modern minds have been deeply shaped by rationalization so that even their emotional reactions are dependent on the rational expectations they have learned to harbour. As I will suggest below, Beck's risk society thesis is a case in point.

Precisely because of our cultural reliance on rationality, it should not come as a surprise that much of the current interest in emotions is directed precisely at scientific findings aimed at improving our scientific control of our emotional responses. This would explain current interest in, for example, the discovery of the so-called "mirror-neurons" (Franks, 2012 [2007]), and its eventual application to the correction of behavioural dysfunctions (Tancredi, 2005).

Very much along the same lines, and keeping in mind the immediacy we attribute to emotion in contrast to reason, it could be argued that the attention we give now to the emotions bears witness to the fact that we have developed a scientific-experimentalist account of our own life stories: That is, we have deeply internalized the procedures of science, accepting only verified knowledge, although "verification", in biographical matters, is expected from emotional experience: in order to accept something as meaningful, we need an emotional experience to corroborate it. While emotional experiences can convey meanings relevant to human life, focusing solely on the emotions can also contribute to what Lourdes Flamarique (2012) has termed the "psychologization of experience", which reflects an experimentalist approach to human life imported from scientific procedures.

Thus, while rationalization might have triggered the nostalgia for emotions, our approach to emotions, and ultimately to experience is deeply influenced by the results and the procedures of experimental science. In my view, this is a clear sign that emotions have become a privileged site of social reflexivity. Indeed, nowadays we do not merely have, or long to have, emotional experiences; instead, we have assimilated a wide range of scientific knowledge (psychological, neurological, and medical) about our emotions so that - as Eva Illouz has argued - we find ourselves developing 
meta-emotions, i.e., "emotions about emotions": we employ them in an effort to develop a certain personality and improve our communication skills; they are a crucial element in every self-help book, as well as in every course on emotional management.

\section{The issue of authenticity}

For sure, the fact that we can work on our emotions rationally is nothing new. Ethics, Rhetoric, Poetics, have always worked on this assumption. Yet, as is apparent in Illouz's analysis of the role of psychologists in organizations (Illouz, 2008), or in Arlie R. Hochschild's studies on emotional work (2003), the modern emphasis on emotional management does not necessarily relate to an ethical outlook, but is rather framed by experimental science and subordinated to certain external ends, more or less incorporated by individual rational agents. This "managerial" framing has raised issues of alienation and authenticity (Salmela, 2009), both at the micro and at the macro level, which are relevant precisely because - as Taylor (1992) has stressed - authenticity, being true to oneself, is one of the values we most cherish as an integral part of our romantic self-conception.

Critiques of alienation raised from the micro approach include Hochschild's own studies on emotional management in terms of "surface acting" or "deep acting", an approach which owes much to Stanislavski's method acting, as well as to Goffman's notion of "dramaturgy"; a prominent criticism of alienation raised from a macro-approach is Stepjan Mestrovic's passionate critique of what he calls the "post-emotional society". This "post-emotionalism", which echoes Riesman's work, The Lonely Crowd (1953), is the result of "the manipulation of emotions by self and others into a bland, mechanical, mass-produced yet oppressive ethic of niceness" (Mestrovic, 1997: 44):

Being "nice" - he notes - is a fascinating emotion, a sort of hybrid between being polite but reserved to strangers from inner-directed days to the stereotypically American habit of being superficially cordial yet also distant. Being nice is an intricate act that involves the manipulation of self and others in highly predictable and deliberate ways, including: one's physical appearance, language, tone, eye contact, choice of clothing, smile, choice and length of conversation, among a myriad of other factors. (Mestrovic, 1997: 51)

In Mestrovic's view, such management of emotions - the MacDonaldization of emotions, as he puts it in another place (1997: 98) - amounts to their lack of authenticity, for it severs any relevant connection to action. Interestingly, Mestrovic makes action the criterion of the authenticity of emotions:

In previous eras, one expected that emotion could lead to action of some sort, but in today's postemotional society, this "natural" relationship between emotion and action has been permanently severed. Emotions serve no appreciable purpose as such, and the more useless one's emotions are, the more one demonstrates to the peer group 
that one has attained the level of prestige that makes the owning of emotions a luxury that one can afford. (1997: 55)

Deprived of their connection to action, emotions would become a luxury: something that can be experienced and exhibited, without commitment in real life (1997: 56); something which is acted out on a mere aesthetic level. From this perspective, too, we find that rationalization is still a powerful force (1997: 89), the main force operating in late-modern societies, only slightly moderated by ever more ephemeral and discontinuous manifestations of collective effervescence. For the most part, according to Mestrovic, "postemotional rituals are mechanical, routinized attempts to simulate authentic collective effervescence" (1997: 111).

While Mestrovic's observations don't lack plausibility in certain cases, they don't leave much room for individual and collective agency. His ambitious account is useful to highlight some black spots in our culture, but provides no significant tools for understanding how authenticity can be present in social interactions and individual lives. The social scientist's privileged position results in his case in the practical disregard for personal elaboration of cultural and social responses. This sociological radicalism makes apparent the need for providing a more balanced theoretical account that allows us to understand the changes we observe in the emotional regime without imposing a distorted view of individual experience.

From this perspective, I would briefly like to consider what can be gained theoretically from viewing contemporary emotional reflexivity, as it is found in emotional management or in the self-help culture, in the light of the reflexivity that, according to Beck (1994), characterizes late-modern societies. In a way, this move involves placing ourselves on the opposite side of the theoretical spectrum: instead of stressing unconscious internalization of social requirements, we focus on an extremely conscious attitude towards social developments.

\section{Theories of late modernity and the sociology of emotions}

Indeed, even though the works of Illouz or Hochschild, as well as that of Scheff, contain important indications that allow for a theoretical link between the contributions of the sociology of emotions and the theories of late modernity advanced by contemporary authors like Beck, Giddens, Lasch, and, in other aspects, Bauman, the link has not yet been developed in the literature. And this despite the fact that, when developing their theories about the transformations of modern societies, these authors have given important suggestions that would establish a link with the sociology of emotions.

\section{a) The macro approach: theories of late-modernity}

For one thing, social theory, under the conditions of "reflexive modernity" (Beck, Giddens and Lash, 1994), is presented as a theory of individualization, which in his 
preface to Beck and Beck-Gernsheim's Individualization. Institutionalized Individualism and Its Social and Political Consequences (2001), Bauman describes as follows:

Casting members as individuals is the trademark of modern society. That casting, however, was not a one-off act. It is an activity re-enacted daily. Modern society exists in its activity of "individualizing", as much as the activities of individuals consist in that daily reshaping and renegotiating of their mutual engagements which is called "society". (2001: xiv)

"Individualization", as Beck notes, "means that the standard biography becomes a chosen biography, a 'do-it-yourself' biography (Ronald Hitzler), or, as Giddens says, a 'reflexive biography'" (Beck, 1994: 15). This development is accompanied by the rise of identity movements - defined by the individual seeking direction -, a context in which the emotions are bound to take on a special relevance as significant evidence for who we are and how we understand the social world in which we shape our own identity.

Moreover, the presence of emotions in contemporary societies could be taken as an indication of the growing "psychologization" of social life, already highlighted decades ago by Arendt (1958) or Sennett (1977). Such "psychologization" is in tune with the contemporary discourse on the "death of sociology", to the extent that it involves the fragmentation/dissolution of its subject matter - i.e., society; more generally it is also in tune with the waning of social bonds, which entails "the dissipation of a sense of being part of an inherited narrative structure that is larger than oneself" (Pugmire, 2005: 7). With this, the question of identity tends to adopt new forms and sources.

Indeed: the contemporary rise of narratives of the self in both a traditional and virtual media, in which emotional expression comes to the fore, is a highly significant indication of the path taken in late modernity by the search for and reconstruction of identity. This path constitutes a unique blurring of boundaries between the public, the private and the intimate.

Now, in attempting to relate the social theories of late modernity with the sociology of emotions we discover an opportunity to relate the macro and the micro approaches to social life, in a way that allows us to enrich both lines of research, as well as our understanding of the structural and cultural context of human agency.

Indeed: as Turner and Stets (2009: 1) noted, "increasingly emotions are seen as a crucial link between micro and macro levels of social reality". This is not just a comment made on the side of sociologists of emotions. Giddens himself had made a particularly explicit note on the relevance of the sociology of emotions for social theory in the introduction he wrote for Scheff book Microsociology. Discourse, Emotion and Social Structure (1990). On that occasion, Giddens remarked that Sheff's intention was precisely to develop a "new explanation of the nature of social life and its relationship with language and human reflexivity, which is why he insists on the importance of a theory of emotion" (Giddens, 1990: ix). Indeed, in contrast with the cognitive interpretations that have prevailed in social theory, Scheff's focus on emotions brings fresh air to the analysis of social relations, and highlights their importance for strengthening or severing the social bond. 
One might object that Scheff's approach still falls short by not taking sufficiently into account the macro-sociological perspective. This is a critique usually raised against most sociology of emotions. Yet, as Turner and Stets observe, Scheff is one of the authors who has tried to bridge the gap between micro and macro approaches, while providing empirical data (Turner and Stets, 2009:313). As a matter of fact, by developing his own methodology - part/whole analysis - Scheff purports to integrate the micro-analysis of discourse with the societal level, thereby giving meaning to the very idea of social reflexivity:

This kind of part/whole structure may be a way of giving concrete meaning to the abstract concept of reflexiveness, the kind of self-referencing which gives rise to self-awareness. (Scheff, 1997: 57).

On the other hand, and in contrast with Scheff's bottom-up approach to social life, theorists of late modern societies have provided us with a number of insights - often conveyed in metaphorical terms - useful to articulate a macro-approach, which could serve as background for micro-sociological analysis.

Let us think, for example about Beck's account of late-modern society as a "risk-society" (Beck, 1992, 2000). As we know, in Beck's view, the emergence of incalculable risks, which defy the usual notions of rationalization, as well as the increasing public awareness of the limitations of such rationality, represent a turning point and define a new phase of modernity; this turning point is marked by a new kind of reflexivity, which is the defining feature of his "risk society" thesis, and is at the core of what he calls "reflexive modernity". For Scott Lash, on the other hand, the "risk society" is characterized by the fact that many biographies are increasingly constructed and narrated in terms of risk calculations - be it health risks, monetary risks, life risks, etc.

The risk society is thus not so much about the distribution of "bads" or dangers as about a mode of conduct centred on risk. This is seen not just in relationship to environment, or work, or poker playing. It is instantiated in the self-construction of life narratives described by Beck and Giddens, in which a probabilistic calculative mode of regulation imparts narrativity to the life-course. (Lash, 1994: 141)

Bauman's characterization of late modern societies as "liquid societies" - another suggestive metaphor - (Bauman, 2003, 2005) also finds resonance within this approach. At the beginning of Does Ethics Have a Chance in a World of Consumers?, he wrote:

Life appears to be moving too fast for most of us to follow its twists and turns, let alone anticipate them. Planning a course of action and sticking to the plan is an endeavour fraught with risks, whereas long-term planning seems downright dangerous. Life trajectories feel as if they are sliced into episodes... Worry and apprehension about the sense and destination of the journey are as abundant as the pleasures promised by this world full of surprises, this life punctuated by "new beginnings". (Bauman, 2008: 1-2) 
Bauman stresses the ambivalent character of the emotional reactions generated by liquid modernity, whose very structure, or lack of it, makes life a risky venture with all the positive and negative connotations associated with it. This approach helps us make sense of the "emotional atmosphere" of late modern societies. Indeed: both the awareness of risk, as well as risk calculation, are likely to trigger a number of emotional reactions associated with disaster preparedness and being prepared for making sense of disaster, which are at the basis of some cultural reactions that figure conspicuously in contemporary Western societies. Among these we could include the proliferation of victimisation (González, 2013), along with the revival of certain forms of religiosity, which Weber linked to the cultural effort of making sense of irrational forces and suffering (Wilkinson, 2013).

More generally, risk-awareness and discourses on risks and uncertainties also seem to be fundamental to other prominent aspects of our emotional culture, such as the presence of fear and anxiety in many spheres of contemporary life (Bauman, 2008: 13); emotions, which cannot be considered apart from changes taking place at the macro level. Thus, in his analysis of the culture of the new capitalism, Richard Sennett recalls Bauman's motif of liquid modernity to describe the consequences of de-institutionalization of the work-place and its impact on individual psychology:

The system produces high levels of stress and anxiety among workers, as I and many other researchers have found [...] One way to contrast this situation to the pyramidal firms I studied thirty years ago lies in the emotional difference between anxiety and dread. Anxiety attaches to what might happen; dread attaches to what one knows will happen. Anxiety arises in ill-defined conditions, dread when pain or ill-fortune is well defined. Failure in the old pyramid was grounded in dread; failure in the new institution is shaped by anxiety. (Sennett, 2006: 52-53)

Instead of anxiety, Frank Furedi prefers to speak of a "culture of fear" (1997), and, raising the discussion to still another level of reflexivity, suggests that the risk society thesis has played a significant role in the advent of such culture. At this point, however, we should not forget that perceptions of risk, as well as the emotional responses to it, differ from one culture to another, and are not dependent on discourses alone.

As the Historian of Middle Ages Barbara Rosenwein writes, "more than one emotional community may exist - indeed normally does exist - contemporaneously, and these communities may change over time" (2006: 2). She compares emotional communities to Foucault's "discourses" ("shared vocabularies and ways of thinking that have a controlling function, a disciplining function"), to Bordieu's habitus ("internalized norms that determine how we think and act and that may be different in different groups"), or to " 'group styles' in which 'implicit, culturally patterned styles of membership filter collective representations' that may include 'vocabularies, symbols, or codes'" (2006: 25).

Yet, when it comes to emotions, not everything can be reduced to discourses and cultural practices. From a geopolitical perspective Dominique Moïsi (2009) has argued that the culture of fear is quite restricted to the Western World - Europe 
and America -, and interprets it as a consequence of perceived loss of economic and political power; by contrast, other areas - Chiindia, the Arab World -, whose perception of their place in the geopolitical map is different, would be dominated by other emotions. While this kind of analysis is surely subject to many criticisms, it serves to the purpose of highlighting the idea of a diversity of emotional cultures, which are influenced not only by cultural factors but also by structural ones.

From this perspective, if the risk-society thesis has found particular echo in western societies, it is only because it has resonated within a specifically modern attitude - the search for certainty in mathematical calculation - and in a particular global context, defined for uncertainty. Thus, as McMylor points out, in his book Risk, Uncertainty and Profit, economist Frank Knight distinguished between "risk" and "uncertainty" exactly in those terms:

Risk refers to situations in which mathematical probability can be allocated to account for the perceived randomness of outcomes, and uncertainties refer to situations in which randomness cannot be expressed in terms of mathematical probability. (McMylor, 2006: 195)

In doing so, economic rationality epitomizes what Weber took to be the defining feature of the process of modernization. The conjunction of cultural and structural factors that impinges upon the emotional culture of contemporary western societies is to be recognized in the fact that this "specific modern attitude", which searches for certainty in mathematical calculation, has been institutionalized in economic science, and permeates a multitude of our cultural practices and political decisions. This, however, means that when risks become incalculable, we are at a loss, perhaps more so than people from other cultural backgrounds. As Wilkinson writes,

[t]he more we are disposed to place an unquestioning faith in the efficiency of rational process and technical procedure the more likely it is that we shall be shocked and distressed when ideal expectations are betrayed by the harsh realities of lived experience. (2009: 33)

Wilkinson's words point at one of the defining features of late-modern emotional reflexivity: the inability to deal with what escapes rational expectations. By stressing the liquid character of contemporary social life, Bauman also suggests the insufficiency of inherited "conceptual nets" for orientating ourselves towards this new emotional reality (Lash, 1999: 1-17). The rational tool meant to control social developments, supposedly provided by social sciences, is found missing:

Our plight, once cast into such a setting and obliged to act in it, is not made any easier by the "conceptual nets" we have inherited or learned to use to grasp the elusive realities, or by the vocabularies we commonly deploy to report our findings. So many concepts and words intended to convey our meaning to ourselves and others now prove unfit for the purpose. We desperately need a new framework, one that can accommodate and organize our experience in a fashion that allows us to perceive its logic and 
read its message, heretofore hidden, illegible, or susceptible to misreading. (Bauman, 2008: 2)

By not giving up the hope of discovering a new framework, Bauman shows the need for developing cognitive tools that are adequate for understanding a changing world. Yet, according to his discourse, part of the difficulty would lie in the fact that cognitive tools alone are not adequate to apprehend the emotional side of our culture, which is responsible for the fluidity of change. Could we remain content with such a conclusion? Should social theory run the same fate as society, and become a "liquid" social theory?

It is perhaps at this point where the ambitious theoretical frames provided by risk-society theorists need be supplemented with modest bottom-up approaches, which, departing, in a more analytic way, from individual emotional reactions to the society and culture, can introduce necessary corrections in the general framework.

b) The micro-approach: insights from the sociology of emotions

Indeed, as shown by Scheff (1997), or Kemper (1990), by making emotions an object - or a perspective - of social analysis, and by highlighting aspects of social interaction, relevant for the agents but often hidden to the social theorist, we can "validate" or "refute" the hypothetical effects that, according to current social theory, the existing social structure has on social behavior; in this way, we can introduce corrections to that theoretical framework. As Scheff writes:

Quantitative analysis leads to verification or disconfirmation of a hypothesis. But verification is the third step in part/whole morphology. Before taking the last step, it is usually necessary to take at least one of the earlier steps: exploration (conventional eyewitness field work using qualitative methods), and/or microanalysis of single specimens and comparison of specimens. (1997: 9)

Of course, any talk of "validation" or "verification" should be done carefully, for the knowledge of social structures that we can "validate" from the perspective of the sociology of emotions depends, to a significant degree, on the perception of the social structures entertained by the agents themselves, which, as mentioned above, is in turn modulated by culture. So, in undertaking the sociology of emotions, we cannot dispense with cultural interpretation. This has to do with the fact that emotions, such as shame, pride, envy, resentment, etc. are not only or even primarily a static reflection of certain structures. Instead, they announce the agents' value-laden response to events perceived as significant and, in this sense, they are also a vehicle of relational subjectivity, which uses certain structures and interprets the cultural means at their disposal without exhausting them (see Pugmire, 2005: 6).

Emotions indeed can be seen as carriers of meaning and value and, as such, as cultural events, although of a peculiar kind because, unlike other cultural manifestations, they are embodied carriers of meaning and value. Thus, while stressing the cultural and social element of emotions is important for understanding their relevance 
as sites for social analysis, we would entirely miss their contribution to social theory were we to forget the basic biological dimension that defines their embodiment. This was precisely what Durkheim took into account when he classified emotions as "psycho-social phenomena", rather than merely "sociological phenomena":

As for their individual manifestations, these are indeed, to a certain extent, social, since they partly reproduce a social model. Each of them also depends, and to a large extent, on the organopsychological constitution of the individual and on the particular circumstances in which he is placed. Thus they are not sociological phenomena in the strict sense of the word. They belong to two realms at once; one could call them socio-psychological. (Durkheim, 1964: 8-9)

While he recognized that emotions entailed a social element, and were also influenced by history (Durkheim, 1964:33-34), he did not lose sight of their dependence on the psychological and organic constitution of any given individual. This is why he considered them "hybrid" phenomena, which "interest the sociologist without constituting the immediate subject matter of sociology" (Durkheim, 1964: 9). As a matter of fact, it is precisely the bio-psycho-social nature of emotion (Theodosius, 2008) that makes it so amenable to interdisciplinary research (Kemper, 1990) and explains the methodological difficulties involved in the practice of any sociology of emotions (Turner and Stets, 2009: 314-315).

Yet, the fact that emotions incorporate thoughts and values makes them fruitful as "tools" of cultural and social analysis, precisely from the point of view of a comprehensive sociology. This can be seen, for example, in the writings of Eva Illouz $(1997,2007,2008,2012)$, who has extensively explored the origins of the current therapeutic-emotional style and how persons from all kinds of social backgrounds have appropriated the language of psychology. Taking note of the way these and other cultural developments have influenced how people frame their emotional experiences is important to appreciate the historical dimension of our emotional lives, the changing nature of emotional regimes.

Of course, while social and cultural norms can frame and make recognizable our emotions from the outside, they cannot entirely recreate them in absence of their proper objects. Thus, no matter how insightful these studies may be, they need to take into account the basic fact that emotions involves organic affection and neurological activity that often goes unconscious and is irreducible to social and cultural norms (Turner and Stets, 2009: 8). Yet, while organic affection is essential to the very concept of emotion, human emotion requires something more than neurological activity (González, 2011, 2015): emotions are meaningful for the subject; they speak to her about her relation to the world: they are commentaries upon our concerns (Archer, 2003: 195), they are sources of self-knowledge; along with our sociality, they are building blocks of our personal identity. This is why, by analyzing the emotional response of any given subject, we are doing something more than replicating a social or a cultural norm; we are having a limited but privileged access to a subjective experience of meaning and value; an access to the site where meaningful cultural elaboration begins to take place. 


\section{References}

Alberti, Fay Bound (Ed.) (2006), Medicine, Emotion and Disease, 1700-1950. Houndmills, Basingstoke, Hampshire and New York, Palgrave Macmillan.

Archer, M. S. (2003), Being Human. The Problem of Agency, Cambridge, UK, Cambridge University Press.

Arendt, H. (1958), The Human Condition, Chicago, IL, The University of Chicago Press.

Barbalet, J. (Ed.) (2002), Emotions and Sociology, Oxford, UK, Blackwell Publishing.

Bauman, Z. (2001), Foreword to Ulrich Beck and Elisabeth Beck-Gernsheim, Individualization. Institutionalized Individualism and Its Social and Political Consequences, London, Thousand Oaks and New Delhi, Sage, pp. xiv-xix.

Bauman, Z. (2003), Liquid Love. On the Frailty of Human Bonds, Cambridge, UK, Polity Press.

Bauman, Z. (2005), Liquid Life, Cambridge, UK, and Malden, MA, Polity Press.

Bauman, Z. (2008), Does Ethics Have a Chance in a World of Consumers?, Cambridge, MA, Harvard University Press.

Beck, U. (1992), Risk Society. Towards a New Modernity, London, Sage.

Beck, U. (1994), “The reinvention of politics: towards a theory of reflexive modernization", in U. Beck, A. Giddens, and S. Lash (Eds.), Reflexive Modernization. Politics, Tradition, and Aesthetics in the Modern Social Order, Cambridge, UK, Polity Press, pp. 1-54.

Beck, U. (2000), The Risk Society and Beyond. Critical Issues for Social Theory, London and Thousand Oaks, CA, Sage.

Beck, U., A. Giddens, and S. Lash (Eds.) (1994), Reflexive Modernization. Politics, Tradition, and Aesthetics in the Modern Social Order, Cambridge, UK, Polity Press.

Beck, U., and E. Beck-Gernsheim (2001), Individualization. Institutionalized Individualism and Its Social and Political Consequences, London, Thousand Oaks, CA, and New Delhi, Sage.

Berezin, M. (2005), "Emotions and the economy", chapter 6 in N. Smelser and R. Swedberg (Eds.), The Handbook of Economic Sociology, Princeton, NJ, Princeton University Press, pp. 109-126 (2 ${ }^{\text {nd }}$ edition).

Bolton, S. C. (2000a ), “Nurses as managers: between a professional rock and an HRM hard place?", Human Resource Development International, 3 (2), pp. 229-234.

Bolton, S. C. (2000b), “Who cares? Offering emotion work as a 'gift' in the nursing labour process", Journal of Advanced Nursing, 32 (3), pp. 580-586.

Bolton, S. C. (2005), Emotion Management in the Workplace. Management, Work and Organisations, Basingstoke, UK, Palgrave Macmillan.

Bolton, S. C., and C. Boyd (2003), “Trolley Dolly or skilled emotion manager? Moving on from Hochschild's managed heart", Work, Employment and Society, 17 (6), pp. 289-308.

Campbell, C. (2005 [1987]), The Romantic Ethic and the Spirit of Modern Consumerism, Alcuin Academics, Oxford, UK, Blackwell Publishing.

Collins, Randall (2014), "Interaction ritual chains and collective effervescence", in Christian von Scheve and Mikko Salmela (Eds.), Collective Emotions. Perspectives from Psychology, Philosophy, and Sociology, Oxford, UK, Oxford University Press, pp. 299-310. 
Cuin, Charles-Henry (2001), “Emotions et rationalité dans la sociologie classique: les cas de Weber et Durkheim", Revue Européenne des Sciences Sociales, XXXIX (120), pp. 77-100.

Damasio, A. (1994), Descartes' Error. Emotion, Reason, and the Human Brain, New York, Putnam and Sons.

Dell' Aquila, Paolo (2014), “The sociology of sport actor: from Norbert Elias' 'de-controlled control of emotion' to postmodern and reflexive sport subcultures", Italian Sociological Review, 4 (1), pp. 117-131.

De Rivera, J. (2014), "Emotion and the formation of social identities", in Christian von Scheve and Mikko Salmela (Eds.), Collective Emotions. Perspectives from Psychology, Philosophy, and Sociology, Oxford, UK, Oxford University Press, pp. 17-231.

Durkheim, E. (1964), Rules of Sociological Method, New York, Collier-Macmillan, and London, The Free Press.

Ekman, P. (1994), The Nature of Emotion. Fundamental Questions, Oxford, UK, Oxford University Press.

Elias, N. (1998), On Civilization, Power, and Knowledge. Selected Writings, edited and with an introduction by Stephen Mennell and Johan Goudsblom, Chicago and London, The University of Chicago Press.

Elias, N. (2003), "Sport und Spannung im Process der Zivilisation”, in Gesammelte Schriften, Band 7, Hrsg. im Auftrag de Norbert Elias Stichting Amsterfdam, vom Rinhard Blomert, Heike Hammer, Johan Heilbron, Anette Treibel and Nico Wiltedink, Suhrkamp, Baden-Baden.

Fineman, S. (Ed.) (2007 [2000]), Emotion in Organizations, Los Angeles, London, New Delhi and Singapore, Sage ( $2^{\text {nd }}$ edition).

Flam, H. (2002), Soziologie der Emotionen: eine Einführung, Konstanz, Germany, UVKVerlagsgesellschaft.

Flamarique, L. (2012), "From the psychologization of experience to the priority of emotions in social life", in A. M. González (Ed.), The Emotions and Cultural Analysis, Burlington, VT, Ashgate, pp. 51-68.

Franks, David D. (2012 [2007]), “Neurosociology”, in George Ritzer (Ed.), Blackwell Encyclopedia of Sociology Online, Oxford, UK, Blackwell Publishing, Blackwell Reference Online.

Furedi, Franck (1997), Culture of Fear. Risk-Taking and the Morality of Low Expectation, London, Cassell.

Giddens, A. (1990), Foreword to Thomas Scheff, Microsociology. Discourse, Emotion and Social Structure, Chicago, IL, The University of Chicago Press, pp. ix-xiv.

González, A. M. (2011), “Naturaleza y elementos de una concepción cognitivo-práctica de las emociones", Pensamiento, 67 (253), pp. 487-516.

González, A. M. (2012), “Emotional culture and the role of emotions in cultural analysis", in A. M. González (Ed.), The Emotions and Cultural Analysis, Burlington, VT, Ashgate, pp. 1-18.

González, A. M. (2013), “La víctima del destino”, in Flamarique and D'Oliveira (Eds.), Emociones y Estilos de Vida, Madrid, Biblioteca Nueva, pp. 157-177.

González, A. M. (2015), “Emoción, sentimiento y pasion en Kant”, Trans-Form-Açao, Marília, 38 (3), pp. 75-98. 
González, A. M. (2016), “The recovery of action in social theory: acting out of sentiment, acting out of character, acting out of interest, acting out of will", in Mark Alznauer and Jose Maria Torralba (Eds.), Theories of Action and Morality. Perspectives from Philosophy and Social Theory, Hildesheim, Zürich and New York, Georg Olms Verlag, pp. 79-111.

Hochschild, A. R. (2003 [1983]), The Managed Heart. Commercialization of Human Feeling, Berkeley, University of California Press.

Hochschild, A. R. (2007), The Commercialization of Intimate Life. Notes from Home and Work, Berkeley, Los Angeles and London, University of California Press.

Hogan, Patrick Colm (2011), What Literature Teaches Us about Emotions, Cambridge, UK, and New York, Cambridge University Press.

Illouz, E. (1997), Consuming the Romantic Utopia. Love and the Cultural Contradictions of Capitalism, Berkeley and Los Angeles, University of California Press.

Illouz, E. (2007), Cold Intimacies. The Making of Emotional Capitalism, Cambridge, UK, Polity Press.

Illouz, E. (2008), Saving the Modern Soul. Therapy, Emotions, and the Culture of Self-Help, Berkeley, University of California Press.

Illouz, E. (2012), Why Love Hurts. A Sociological Explanation, Cambridge, UK, Polity Press.

Joas, H. (1993), Pragmatism and Social Theory, Chicago and London, The University of Chicago Press.

Kagan, Jerome (2007), What is Emotion? History, Measures, and Meanings, New Haven, Yale University Press.

Keen, Suzanne (2007), Empathy and the Novel, Oxford, UK, Oxford University Press.

Kemper, Th. (1990), "Themes and variations in the sociology of emotions", in T. Kemper (Ed.), Research Agendas in the Sociology of Emotions, New York, State University of New York Press.

Kenny, A. (1992), The Metaphysics of Mind, Oxford, UK, Oxford University Press.

Kenny, A. (1994 [1963]), Action, Emotion, and Will, Bristol, UK, Thoemes Press.

Lash, S. (1994), "Reflexivity and its doubles: structure, aesthetics, community", in U. Beck, A. Giddens and S. Lash (Eds.), Reflexive Modernization. Politics, Tradition, and Aesthetics in the Modern Social Order, Cambridge, UK, Polity Press, pp. 110-173.

Lash, S. (1999), Another Modernity. A Different Rationality, Oxford, UK, Blackwell Publishing.

Lazarus, R. (1994), Passion and Reason. Making Sense of Our Emotions, New York, Oxford University Press.

Le Breton, D. (2004), “The anthropology of risk-taking behaviours", Body E Society, Sage Publications, 10 (1), pp. 1-15, DOI: 10.1177/1357034X04041758

Ledoux, J. (1999), The Emotional Brain. The Mysterious Underpinnings of Emotional Life, London, Phoenix.

Lemmings, David, and Ann Brooks (2014), Emotions and Social Change. Historical and Sociological Perspectives, New York, Routledge.

Martín Moruno, D. (2011), "Romantic feelings: Medicine and emotions in the $19^{\text {th }}$ Century", paper presented at the Workshop "Health and Emotions", Pamplona, October. 
McMylor, P. (2006), “Economics and risk”, in Gabe Mythen and Sandra Walklate (Eds.), Beyond the Risk Society. Critical Reflections on Risk and Human Security, New York, Open University Press, pp. 194-210.

Mestrovic, Stjepan G. (1997), Postemotional Society, London, Sage.

Moïsi, D. (2009), The Geopolitics of Emotion. How Cultures of Fear, Humiliation and Hope are Shaping the World, London, The Bodley Heard.

Paster, Gail Kern (2015), “Eschewing politeness: Norbert Elias and the historiography of Early Modern affect", Publications of the Modern Language Association of America, 130 (5), pp. 1443-1449.

Peterson, G. (2014), "Sports and emotions”, in Jan Stets and Jonathan Turner (Eds.), Handbook of the Sociology of Emotions, vol. II, Boston, Springer, pp. 495-510.

Pugmire, D. (2005), Sound Sentiments. Integrity in the Emotions, Oxford, UK, Clarendon Press.

Riesman, D. (1953), The Lonely Crowd. A Study of the Changing American Character, New York, Doubleday.

Rosenwein, B. (2006), Emotional Communities, Ithaca, NY, and London, Cornell University Press.

Salmela, M. (2009), Emotions, Ethics, and Authenticity, Amsterdam and Philadelphia, PA, John Benjamins Publishing.

Scheff, T. (1990), Microsociology. Discourse, Emotion and Social Structure, Chicago, IL, The University of Chicago Press.

Scheff, T. (1991), Emotions and Violence. Shame and Rage in Destructive Conflicts, Lexington, MA, Lexington Books.

Scheff, T. (1994), Bloody Revenge. Emotions, Nationalism and War, Boulder, CO, Westview Press.

Scheff, T. (1997), Emotions, the Social Bond and Human Reality. Part/Whole Analysis, Cambridge, UK, Cambridge University Press.

Sennett, R. (1977), The Fall of Public Man, Cambridge, UK, Cambridge University Press.

Sennett, R. (2006), The Culture of the New Capitalism, New Haven and London, Yale University Press.

Solomon, Robert C. (1976), The Passions, Garden City, NY, Doubleday.

Stearns, Carol, and Peter Stearns (1986), Anger. The Struggle for Emotional Control in America's History, Chicago, The University of Chicago Press.

Stearns, C., and P. N. Stearns (Eds.) (1988), Emotion and Social Change. Toward a New Psychohistory, New York and London, Holmes \& Meier.

Stets, Jan, and Jonathan H. Turner (Eds.) (2006), Handbook of the Sociology of Emotions, vol. I, Boston, Springer.

Stets, Jan, and Jonathan H. Turner (Eds.) (2014), Handbook of the Sociology of Emotions, vol. II, Boston, Springer.

Tancredi, Laurence R. (2005), Hardwired Behavior. What Neuroscience Reveals about Morality?, Cambridge, UK, and New York, Cambridge University Press.

Taylor, Ch. (1992), The Ethics of Authenticity, Cambridge, MA, Harvard University Press.

Theodosius, C. (2008), Emotional Labour in Health Care. The Unmanaged Heart of Nursing, Abingdon, Oxon and New York, Routledge.

Turner, Jonathan, and Jan E. Stets (2009), The Sociology of Emotions, Cambridge, UK, Cambridge University Press. 
Van Krieken, Robert (2014), "Norbert Elias and emotions in history", in David Lemmings and Ann Brooks (Eds.), Emotions and Social Change. Historical and Sociological Perspectives, New York, Routledge, pp. 19-42.

Von Scheve, Ch. (2013), Emotion and Social Structures. The Affective Foundations of Social Order, New York and London, Routledge.

Wassmann, C. (2005), The Science of Emotion. Studying Emotions in Germany, France, and the US, 1860-1920, Chicago, University of Chicago, thesis.

Wilkinson, I. (2009), Risk, Vulnerability and Everyday Life, London and New York, Routledge.

Wilkinson, I. (2013), “The problem of suffering as the driving force of rationalization and social change", The British Journal of Sociology, 64 (1), pp. 123-141.

\section{Acknowledgments}

I acknowledge the comments by colleagues of the CEMID research group, at the Institute for Culture and Society, at the University of Navarra, as well as the feedback received at the Dipartimento di Sociologia in the Università Cattolica del Sacro Cuore (Milan, Italy).

\section{Funding}

This article is part of the projects "Action, Emotions, Identity" (Ref. FFI2012-38737-C03-01), and "Bonds, Emotions and Identity" (Ref. FFI2015-67388-P), funded by the Spanish Ministry of Economy and Competitivity.

Ana Marta González. Associate Professor of Moral Philosophy in the Department of Philosophy at the University of Navarra (Spain) and Researcher of the Institute for Culture and Society at the same institution. E-mail: agonzalez@unav.es

Receção: 02 de novembro de 2015 Aprovação: 13 de fevereiro de 2017 
